\title{
Graham Pont $\quad$ The Cinema as Secular Temple: Ethos, Form and Symbolism of the Capitol Theatre
}

Since the tetraktys is the most important symbol of the Pythagorean school and system, its prominence in the form and decoration of the Capitol Theatre, Melbourne (Australia), suggests that this building was designed in the Pythagorean spirit. The tetraktys encodes the fundamental proportions or harmonies of the musical scale $(1: 2,2: 3$, $3: 4)$ and so one would expect to find these same proportions used in the form and decoration of the Capitol as well as evidence of relevant musical thought and inspiration in the writings of its designers, Walter Burley and Marion Mahony Griffin. Graham Pont explains the significance of the tetraktys in the Pythagorean tradition, identifies the Capitol as a "secular temple" in form and ethos, and indicates possible contemporary influences on the theatre's remarkable motif of the "Crystal Tetraktys" and other symbolism.

Music is a parallel art [to Architecture] in that it appeals to primitive instinct, and is independent of representation of ideas, of literature. Music is, so far, the one great art that has developed in modern times, because it had kept pace with science, as that has clarified the phenomena of sound, and with the mechanical progress that has opened new avenues of musical expression.

—Walter Burley Griffin [Griffin 1940-49, IV, 16]

\section{Introduction}

On 7 November 1999, the Capitol Theatre of Melbourne reopened to the acclamation of a capacity crowd-a notable event in the later history of twentieth-century architecture. This masterpiece of Walter Burley and Marion Mahony Griffin only narrowly escaped demolition in the 1960s but the magnificent auditorium has been acquired by RMIT University, Melbourne, and is being restored to something of its former glory. The occasion was the 75th anniversary of the theatre's first night and the climax was the ceremonial relighting of the famous crystal ceiling — an unforgettable experience.

Suddenly, in a magical blaze above the proscenium, there appeared the shining form of the tetraktys, the triangular cosmogram of the Pythagoreans and their key to the harmony of the world. Centrally positioned, exactly where the heraldic shields and coats of arms were displayed in the noble theatre, the emblem boldly emblazons the high ancestry of this unique and extraordinary cinema (Figs. 1 and 2).

For its opening weeks in 1924, the Capitol featured Cecil B. de Mille's silent epic The Ten Commandments, preceded by an "Atmospheric Egyptian Prologue"- a tableau vivant devised by the theatre's General Manager, James L. Thornley. The dramatic prelude was accompanied by the Capitol Operatic Orchestra and the largest WurliTzer pipe organ in the Southern Hemisphere. ${ }^{1}$ The private opening was a momentous occasion but, apart from the newspaper advertisements and social column listings of the dignitaries present, there was surprisingly little published on the event and hardly any discussion of the illuminated ceiling! ${ }^{2}$ 


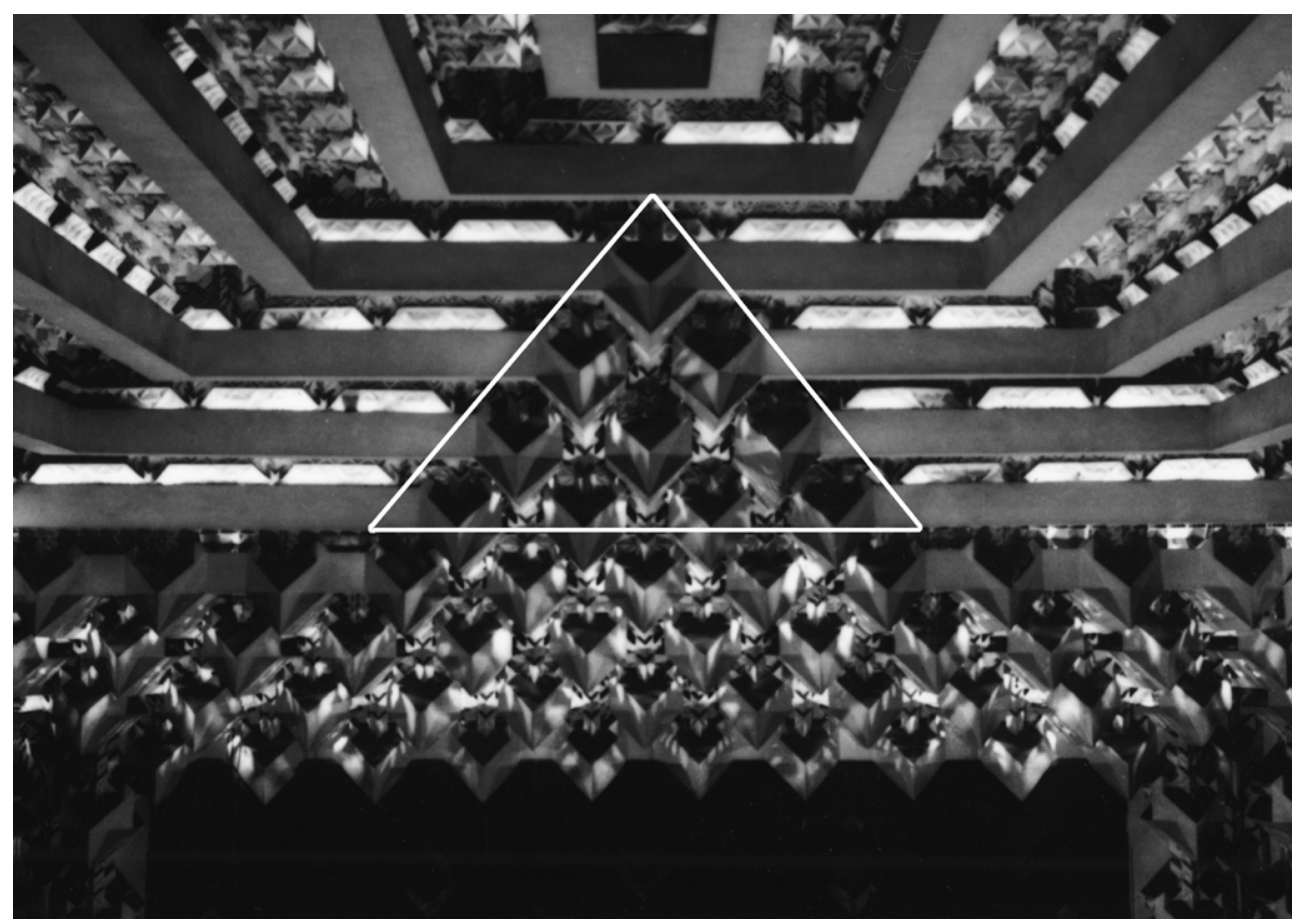

Fig. 1. Capitol Theatre, Ceiling of Auditorium with Crystal Tetraktys above the proscenium. The added triangle encloses the ten lamps of the Tetraktys. (With appropriate lighting the Tetraktys could be enlarged to sides of eight units). From the photograph by Lyle Fowler (1950), Harold Paynting Collection, State

Library of Victoria. Image processing by Keith Lo Bue. Image of the Capitol Theatre in the Pictures

Collection of the State Library of Victoria online at http://www.statelibrary.vic.au/: Accession Number: H92.20/3414

The Capitol took Melbourne by surprise and, though it has always had its admirers (prominent architect and critic Robin Boyd described it as "the finest cinema that was ever built or is ever likely to be built" [Boyd 1965]), it remains an enigma: a profoundly classical building in a city, country and culture pervasively romantic in temperament. While its commercial motivation and mundane purposes are self-evident, the genre, ethos, and significance of this audacious building have never been fully explained.

The Capitol is manifestly a secular temple, and, like many temples, its religious and philosophical origins are esoteric: its creators revealed little of their design rationale, let alone the true sources of their inspiration. As with the plan of Canberra, their deeper artistic intentions were mostly kept secret and are scarcely better understood today than those of the priests who built the Gothic cathedrals or the temples of ancient Egypt. This is especially true of the Griffins' code of architectural ornament and its role in the decoration of the Capitol office block and theatre.

The Capitol is certainly an original creation [Johnson 1977, 107-8; Turnbull and Navaretti 1998, 60-1, 196-8]: what began as a speculative office block and entertainment centre became a temple of the arts-a democratic fane with a transcendental ethos. Unlike most modern entertainment centres, the form, decoration and symbolism of the Capitol look beyond mere 
amusement to true education: some of its glowing imagery is more like the didactic illuminations of sacred manuscripts and stained glass.

Situated at the heart of Melbourne, right opposite the Town Hall and close by the Cathedral of St Paul, the office block of Capitol House, fronting Swanston Street, became the City's tallest building-Australia's first skyscraper. The tower aspired to a higher state too in its form and symbolism, as is made plain by the crowning four-tiered finial that was never built (Fig. 4). This stylised "world tree", borrowed from the stupika of the Hindu stupa [Turnbull and Navaretti $1998,50,58]$, is an axis mundi that would have invited the mind and spirit to transcend the world of commerce, while gracefully complementing - if not openly challenging — the nearby municipal towers and ecclesiastical spires.

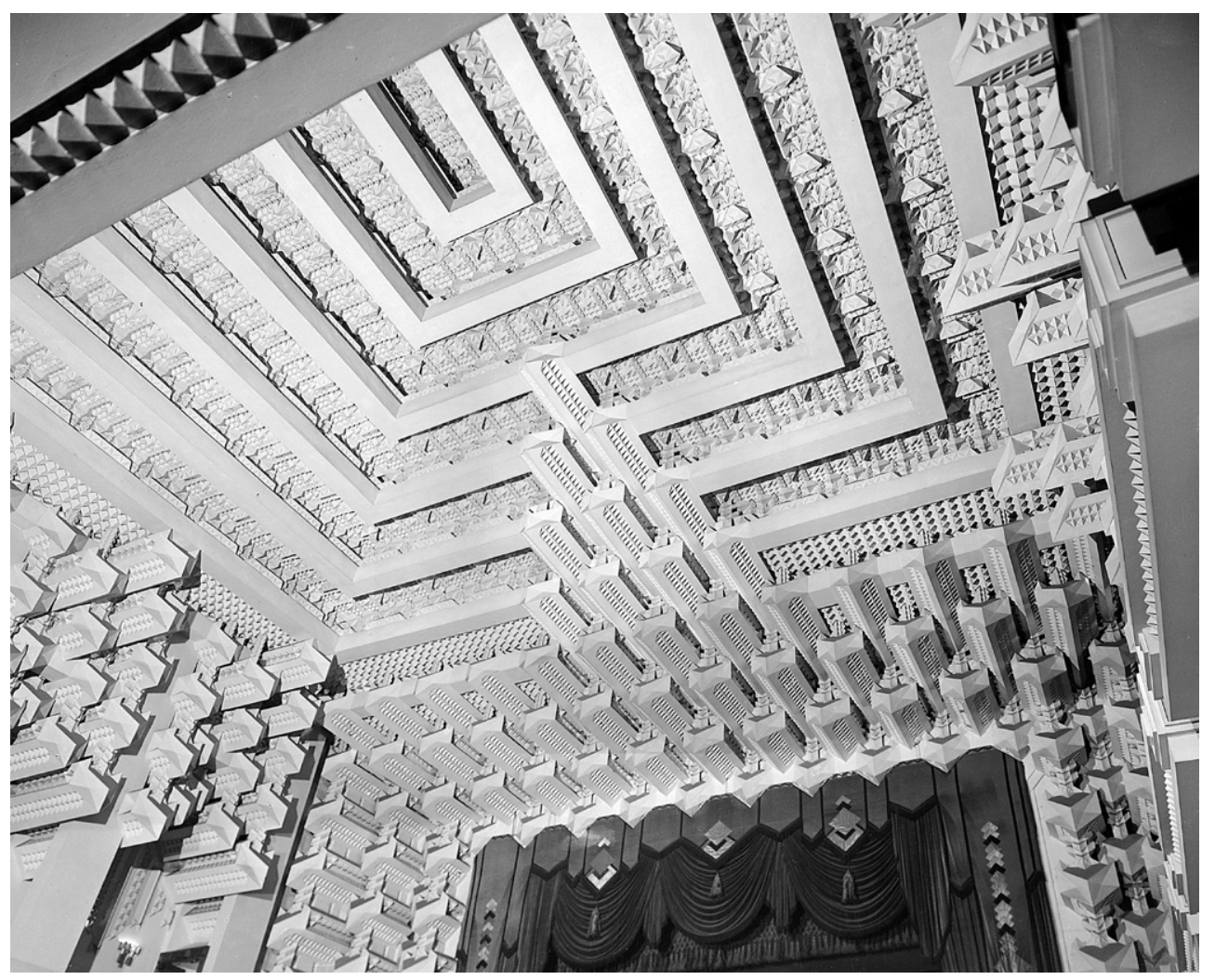

Fig. 2. Another view of the Crystal Tetraktys. Photograph by Lyle Fowler (c.1950). Harold Paynting Collection, State Library of Victoria. Image of the Capitol Theatre in the Pictures Collection of the State

Library of Victoria online at http://www.statelibrary.vic.au/: Accession Number: H92.20/3406

The Capitol also transcended its commercial brief and narrow site in establishing a cosmopolitan ethos. According to the original sense of the word, architecture and city planning become "cosmopolitan" when they imitate the Kosmos or world-order. The term Kosmos is said to have been used by Pythagoras to denote, first, the larger universal system of sun, moon, planets and stars (the "macrocosm") and, second, those analogous lesser orders, such as the temple, the 
house, the tomb and the human body and soul (the "microcosm") [see Raglan 1964, chaps. 1, 14$16]$.

For the Greeks, the "analogy of the macrocosm and the microcosm" extended in a hierarchy of rational symmetries from the constitution of the human being ${ }^{3}$ to that of the family and household (the oikos or villa), to the polis or city-state, and even to the climate or weather. All of these were conceived as complexes of "temperaments" or attunements of the four "elements" (Fire, Air, Water and Earth), the classic constituents of the universal system. This was also the foundation of the Griffins' metaphysics. Linking all levels was the musico-mathematical bond of "harmony": the ultimate cosmos was the "Harmony of the Spheres" and its architectural imitation was what Goethe and others have called "Frozen Music." Cosmetics was supposedly an analogous application of these same principles.

\section{The Crystal Tetraktys}

The Tetraktys occupies a commanding position in both the plan and elevation of the theatre (cf. Fig. 1, Fig. 2 and Fig. 5); and, since the same motif is durchkomponiert in the elaborate configuration of the auditorium walls and box seating, it is surely the emblem of the Capitol-a badge or device with a secret motto. Like the Cross of a later cult, the tetraktys was both a symbol and an article of the faith:

\section{I swear by the discoverer of the Tetraktys \\ Which is the spring of our wisdom \\ The perennial fount and root of Nature}

[Fideler 1987, 28]. ${ }^{4}$

The original disciples of Pythagoras were initiated in silence and sworn to secrecy-hence our sources of information on their beliefs are mostly late, indirect and very imperfect. Despite the occasional revelations of early philosophers (the most important of whom were Plato, Aristotle, and some of their pupils [K.S. Guthrie 1987, 299ff; W.K.C. Guthrie 1962, I: 166ff, 222ff]), the secrets of the old Pythagoreans remain elusive, often little more than subjects of hazy speculation and popular anecdote. Were it not for Plato's Timaeus, the genuine scientific and metaphysical traditions of the sect would have been virtually lost. ${ }^{5}$

The tetraktys is a schema, a geometrical array or "figurate number," named for the four units that form each side of the basic triangle. With its complex symbolism-metaphysical, moral, spatial and musical-the tetraktys is the most concise encoding of the old Pythagorean worldview. It represents a paradigmatic harmonia or regular concatenation of arithmoi, the units or atoms of the Pythagorean universe. In the primitive teaching, the arithmoi (which became the subject-matter of Arithmetic) were represented in patterns of stones or pebbles corresponding to the atoms, monads or irreducible units of reality which were also identified with integers or whole numbers. Every existing object, it was thought, consisted of a finite number of these arithmoi, with the result, as Aristotle reported it, that "things themselves are numbers" and that the universe is a "harmonia and a number" [Metaphysics A 5 986a; W.K.C. Guthrie, 1962, I: 229]. Thus a point was defined or constituted as 1, a line as 2, a plane surface as 3 and the simplest solid as 4 .

The Pythagorean discipline involved an intense study and contemplation of the various mathematical forms or schemata, especially those considered to have metaphysical or moral significance. Mathematics, for the Pythagoreans, was literally the "way of purification," the science that cleansed the mind of worldly illusion and attuned the disciple to the resonant truths of the 
universe. The tetraktys had a very special significance in their discipline as its numbers also encoded the fundamentals of human music and its natural cause, model or template- the cosmic music or "Harmony of the Spheres," which Pythagoras alone could hear. The belief that music was the key to the structure of the world and the ideal model for the human order was shared in various forms by all the old high civilisations [McClain 1976].

Well before the Greeks, the Babylonian and Egyptian priests knew that the "fixed" or structural intervals of the musical scale-the octave, fifth and fourth-could be precisely defined by simple arithmetic divisions of a stretched string, represented in a series of whole number ratios: 1:2 (octave), 2:3 (fifth) and 3:4 (fourth). Some time during the long evolution of the harp and its derivatives from the hunter's bow, musicians discovered that a true octave is invariably obtained by stopping a uniform stretched string at exactly half its length and plucking the residue. Similarly, the interval of a fifth above the fundamental tone of the open string is obtained by stopping the bottom third, and a fourth by stopping the bottom quarter. On the monochord (one of the earliest scientific instruments, which the Greeks called the Kanon), these formative wholenumber ratios revealed the common mathematics of sound and space-and that same mathematics was applied to the division of time. We still read the time of day from a circular representation of the monochord string, divided into its twelve parts. The division of the monochord (sectio canonis) remains a model of scientific demonstration-perhaps the oldest exact lesson still taught in the academy.

The ancients knew that the series of "emporic" or "superparticular" ratios-1:1, 1:2, 2:3, 3:4, 4:5, etc. - was precisely correlated with an inevitable and unvarying transition from harmony to discord, from concord or cosmos to an increasingly disordered chaos. As the early theorists progressed through the series, they recognised the interval of the major third (4:5) and the minor third (5:6) but considered them to be "movable notes"; that is, flexible or unstable intervals and discords as well. They also identified the proportions of the major tone (8:9) and the minor tone (9:10) and, by the same procedure, made the staggering discovery that the semitone could not be precisely defined by a simple whole-number ratio: the ratio of 8:9 cannot be divided by 2 . Thus the semitone had no real number, ${ }^{6}$ no $\log o s$; its proportion was alogon. The ratio of the semitone was both nameless and numberless-ineffable and unthinkable. Plato's equally-tempered semitone (still used today) has the ratio of the twelfth root of 2 [McClain 1978, 97ff, 127ff]. We call that ratio a "surd" or "irrational" number (its decimal value is $1.059463094 \ldots$...).

The Latin term surdus betrays the continuing influence of Pythagorean ideas, for it means "silent," "deaf," or "mute" (that is, unspeakable): the irrational, for the believers, was " $a b$ surd"inharmonious, unintelligible, repugnant. The brilliant geometrical proof that the hypotenuse of a right-angled isosceles triangle had an irrational magnitude was probably discovered by one of the later Pythagoreans, who regarded it as "the shocking exception." Understandably, they tried to hush it up: it refuted their fundamental conviction that everything had a whole number and so was the last thing that Pythagoras himself would have wished to know about!

"Pythagorean triples" like the "marriage triangle" 3-4-5 have been used in surveying and building since at least Egyptian times but the actual influence of Pythagorean mathematics on Classical and Gothic architecture is still disputed. There is no doubt, however, that the traditions of Pythagorean science, speculation and scholarship enjoyed a strong revival during the nineteenth and twentieth centuries, particularly through the influence of people such as Goethe, ${ }^{7}$ Ernst Chladni, Thomas Taylor, Antoine Fabre d'Olivet [1987], George Oliver [1875], Albert von Thimus, H.P. Blavatsky, Edouard Schuré [1912], Victor Goldschmidt [1901], Rudolf Steiner, 
Hans Kayser, Dane Rudhyar [1982], Rudolf Wittkower [1949], Marius Schneider [1955], Rudolf Haase [1969], James Haar [1973-4], Ernest G. McClain [1976, 1978] Luis E. Navia [1990], Joscelyn Godwin [1993] and others.

The renewed interest in cosmic architecture and design was encouraged by the widely-read W.R. Lethaby-though he was by no means a Pythagorean. ${ }^{8}$ Neither exactly was Rudolf Steiner, one of the leading esoteric thinkers of his time; but, like Lethaby, he investigated anew the analogy of the macrocosm and the microcosm [1985]. The Griffins were personally acquainted with Lethaby and, in a letter to Marion dated 17 March 1936, Walter wrote that he used to read a chapter of Steiner before getting up in the morning [Griffin 1940-49, I: 86]. For the immediate problems of practical design, however, they might have found a more useful guide in the writings of Claude Bragdon, whose first book, The Beautiful Necessity [1910], was a series of essays on architecture as "frozen music."9

As with so many preceding centuries of esoteric architecture, there is hardly any informed contemporary comment on the design of the Capitol Theatre-apart from those telling words from the "horse's mouth," such as some anonymous newspaper comments and other notices that appeared in the Australian Home Builder and its successor, Australian Home Beautiful. An example of this is "A Palace for Films and Commerce" in the 15 September 1924 issue of Australian Home Beautiful. ${ }^{10}$ Important hints are also preserved in The Magic of America [Griffin 1940-49].

We are fortunate in having available a large though not complete collection of the architects' working drawings for the Capitol. ${ }^{11}$ While most of these sheets are just the necessary plans, elevations and construction details, others show signs of the creative process, such as the copies of Detail Sheet 255 which have pencil additions and intriguing authorial marginalia [State Library Of Victoria, WD.THE.32, Nos. 468 \& 469] (Fig. 5).

While recognising the dangers inherent in speculative hermeneutics, we believe that the Crystal Tetraktys, which so visibly dominates the auditorium of the Capitol Theatre, is the key to the form and meaning of the monument. Our aim in this essay is to explain the emblem and its symbolism, to establish its relation to the ethos and form of the building and, finally, to explore its connections with the Griffins' own world-view and design philosophy.

\section{Secular Temple}

The basic form of the Capitol is a rock temple or cave sanctuary (the auditorium) which is entered through a portal or propylon (the office tower). The auditorium gave an anonymous but well informed contemporary the "impression of being in a colossal cave cut and chiselled by skilled hands... A thousand projections like trimmed horizontal stalactites, thrust out symmetrically from the sides and roof. Each speaks for the design, and all speak in unison, so that a chorus of units each like a regularised rock-crystal makes a mighty, architectural chorus." This rare appreciation of the crystalline and musical character of the decoration unquestionably reflects the Griffins' own views: it was obviously penned by one of them, most likely Marion. ${ }^{12}$

The Swanston Street facade presents a symbolic gateway to the sanctuary, ${ }^{13}$ the central bay of windows representing the spiritual point of "entrance" at the first floor level with a notional void reinforced by the break in the roof-line and the separation of the paired tribunes below. (Fig. 4) The impression of portal depth is strengthened by a clever use of false perspective or optical tempering: the panels beneath the windows of the central bay are placed somewhat deeper and 
lower than the rest, so that they appear to the casual passer-by to be at the same level but even more deeply recessed. The intention is confirmed, and the effect enhanced, by the actual recessing of the top window of the central bay. The displacement can be seen in [IWC, 5]. ${ }^{14}$

The spiritual entrance to the Capitol is flanked on both sides by three engaged columns or pilasters. Most Greek temples, from the sixth century onwards, have six columns on the front and back sides (the so-called hexastyle). But lengthways, the Capitol resembles in both plan and section a Gothic cathedral with its towering portal, narthex (foyer), ${ }^{15}$ nave (auditorium), sanctuary (stage) and undercroft (basement). ${ }^{16}$

Its sacred models, however, are not just western. The seven-stepped ceiling of the auditorium imitates the oldest monumental form of the temple, the ziggurat [Turnbull and Navaretti 1998, 60-61]; Marion described the form as "an elongated pyramid" [Griffin 1940-49, II: 37] (Fig. 1, Fig. 2 and Fig. 3). Here the invitation to spiritual ascent is dramatically reinforced by the sliding panel at the uppermost level of the auditorium ceiling, which seemingly opened the auditorium to the sky to evoke the feeling of an open-air theatre. The ziggurat motif reappears in the coffers of the street awning and at the base of the pilasters on the main façade, as well as in the three-tiered ceiling over the foyer and rear stalls of the theatre (see [IWC, 2,3,5,6,8 etc.]).

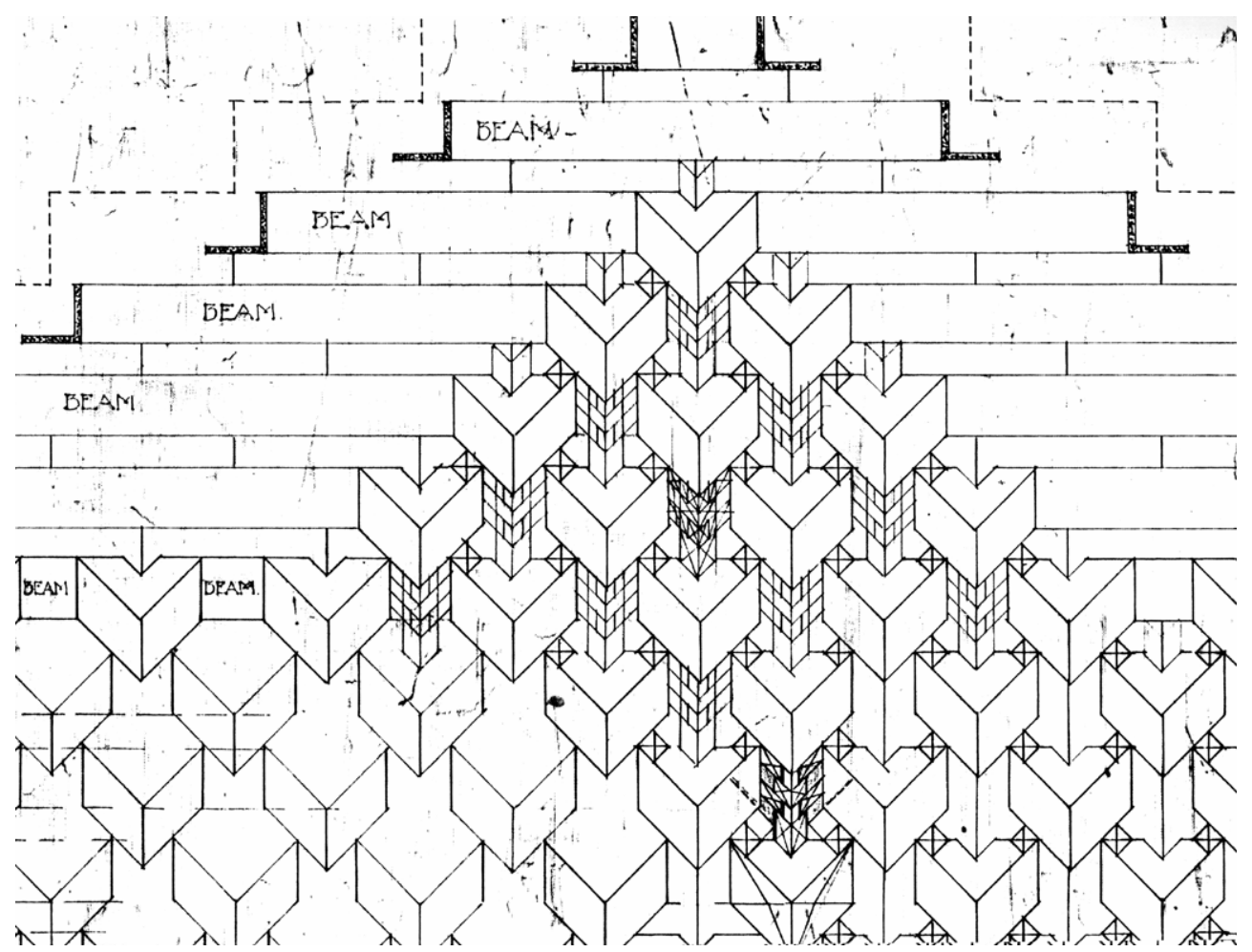

Fig. 3. Capitol Theatre - Part of Detail Sheet 240, Elevation of Proscenium (last dated 1924.4.10), showing the Crystal Tetraktys and ziggurat ceiling-form. ANL, Donald Leslie Johnson Collection of Walter and Marion Griffin Documents. By permission of the National Library of Australia 
The eastern temple was also imitated in the unbuilt spire or finial, the four levels of which would have represented degrees of spiritual ascent towards a higher state indicated by the axis mundi, as in the stupa and its derivative, the pagoda. The form of the stupa, furthermore, is imitated even in the plan of the theatre: on Permit Drawing 3 (VSL) the first floor auditorium appears as a square and the stage as an incomplete and distorted triangle: viewed upright, this arrangement would resemble in outline a stupa with a stepped roof or perhaps a seven-stepped ziggurat with a large cubical base.

If, as we hypothesise, the Capitol Theatre was conceived in the Pythagorean spirit ${ }^{17}$ as a scene, not just of diversion, but of public edification and moral improvement, then the choice of The Ten Commandments for the opening spectacle was far from accidental. ${ }^{18}$ But there might have been other sources of inspiration. Apart from the most obvious, the classical temple and theatre, there are two very relevant conceptions, both represented by the greatest Pythagorean of them all, Plato.

The first is the "Divided Line" of The Republic (VI, 509-10), which, following ancient precedents of spiritual ascent in the sacred mountain, ziggurat, and pyramid, plots the hierarchy of human knowledge from the lowest sensual experience, through the empirical and mathematical sciences, to dialectic or philosophy and points beyond to the ultimate mystical vision. The pronounced vertical symbolism of the Capitol leaves no doubt that the Griffins had hoped for a comparable elevation in the knowledge and taste of the theatre's patrons. ${ }^{19}$

The second is Plato's equally famous "Allegory of the Cave" (The Republic VII, 514; 532). Did the Griffins, we wonder, intend the obvious inference that the audience watching the silent pictures of the cinema was in a somewhat comparable position, epistemologically, to the prisoners in the cave whose perceptions of the real world outside were limited to the shadowy images cast on the wall from the fire behind them?

\section{Pythagorean Forms and Esoteric Symbolism}

On approaching Capitol House from Swanston Street, we encounter the massive veranda awning or sidewalk canopy-twenty-five tons of reinforced concrete pierced by three groups of three transparent coffers or lights. Here we might pause to reflect on Edouard Schuré's observation that "the number three reigns everywhere in the universe" [1912, II: 95] or on Marion Griffin's mysterious reference to "the threefold crystal of Thinking, Feeling and Will" [Griffin 1940-49, III: 467; IWC, 10-13]. Three was the first real number in the Pythagorean system. The architecture and decoration of the Capitol are dominated by three perfect geometrical forms, the circle, the square (double square, cross, cube, etc.) and the triangle [cf. Oliver 1846, I: 552-3].

The ground floor entrance of the Capitol led originally to the lobby, which was demolished in 1964. This had a domed and vaulted ceiling and a lavish decorative scheme also derived from the circle. The horizontal transition from the square entrance area to the semi-circular lobby stairs again reflected the vertical geometry of the stupa. Since time immemorial, the square and the circle have been associated as cosmological symbols, one representing the four-square Earth, the other the dome of the eternal Heavens: how many other cinemas have dared to invoke this sublime iconography?

The triangle is most conspicuous in the crystalline projections that decorate the walls and ceiling of the auditorium, especially in the tetraktys motif. Here the pervasive form is the right- 
angled isosceles triangle of "Pythagoras's Theorem," which also appears in the plan and elevation of the proscenium's "crystal lanterns" (Detail Sheets 69 and 82). According to the Griffins' philosophy, the triangle represents one of the four anthroposophical ethers - the form of light or the "gaseous condition of matter" [Griffin 1940-49, III: 425]. ${ }^{20}$

Thus the triangle-symbol or, for the Griffins, the actual form of light-generates the crystalline decoration of the proscenium, auditorium walls and boxes. Detail Sheet 255 shows in plan how the motif was meant to grow out from a single crystal to a double row, then a triple, and finally a sevenfold rank of over-projecting corbel forms or horizontal stalactites-like a musical crescendo that accompanies the pilgrim to the inner sanctuary. ${ }^{21}$ The climax of this grand progression is the four-rowed tetraktys projecting above and beyond the proscenium arch. The rhythm of these forms forcibly suggests the dynamics of growth and crystal formation but the Griffins may also have intended to convey the effect of waves, a pattern naturally associated with sound. ${ }^{22}$ Note also the overlapping or "telescoping" of the tetraktys motif in the side wall boxes: this echoes the musical device known as "stretto" (the overlapping of themes or phrases that originally appeared further apart, as in the "Amen" chorus of Handel's Messiah) (Fig. 5; cf. Fig. 2).

There is an ingenious example of Pythagorean geometry and metaphysical symbolism in the plan of the proscenium lanterns which clearly recalls the square-and-circle diagrams of Medieval and Renaissance cosmology, particularly the "tetrads" or schematic representations of the "qualities" and "humours" of Hippocratic medicine [cf. Heninger 1977, 2-3; 104; 106; 108; 165; 184; 187, etc.] (Fig. 6). ${ }^{23}$ The ancient medical system was also derived from the four "elements", 24 traditionally ascribed by the Greeks to Empedocles (c.493-c.433 BC), who was considered to have been a follower of Pythagoras. Interpreted as a symbol or microcosm of the Griffins' collateral metaphysic, the crystal lantern becomes not merely a source of light but also of illumination.

There is another hidden cosmogram - a circle divided diametrically into eight equal segments - in the plan of the Icicle Lamp of the entrance vestibule (Detail Sheet 438) [ANL]. This very ancient symbol, the "cosmic wheel", could also represent the Sun and its rays, the plan of a city or, in more complicated forms, the divisions of a tone-circle [Burckhardt 1986, 46-47; McClain 1978, 104; 108; 150ff]. The same geometry (and, perhaps, its symbolism) once informed the highly decorated octagon columns of the theatre foyer. In such refinements, the Griffins evince a degree of philosophical subtlety, spiritual insight and priestly reserve otherwise unknown in Australian architecture. ${ }^{25}$ Titus Burckhardt's arresting characterisation of the Indian temple as a "crystalline image of the cosmos" might almost be applied to the auditorium of the Capitol Theatre [1986, 25].

According to the Pythagoreans, forms are expressible as numbers and vice versa. Ten is the decad, the most perfect number, the sum of the tetraktys, which is a triangular or pyramidal number. Its constituent numbers $(1+2+3+4)$ constitute the tetrad which "generates or begets the decad" [Bell 1946, 153-4; Theon of Symrna 1979, 62]. The decad comprehends "all differences of numbers, reasons, species and proportions" [S.K. Guthrie 1987, 133]: in other words, it is the natural basis of the decimal or ten-finger system of counting. The facade of the Capitol is divided vertically into two symmetrical sets of five bays separated by the central "entrance." Horizontally, the facade is divided into ten floors above the street level: on Permit Drawing 7 (Fig. 4), the main floors are numbered accordingly (the ground floor being treated as a stylobate or podium). 


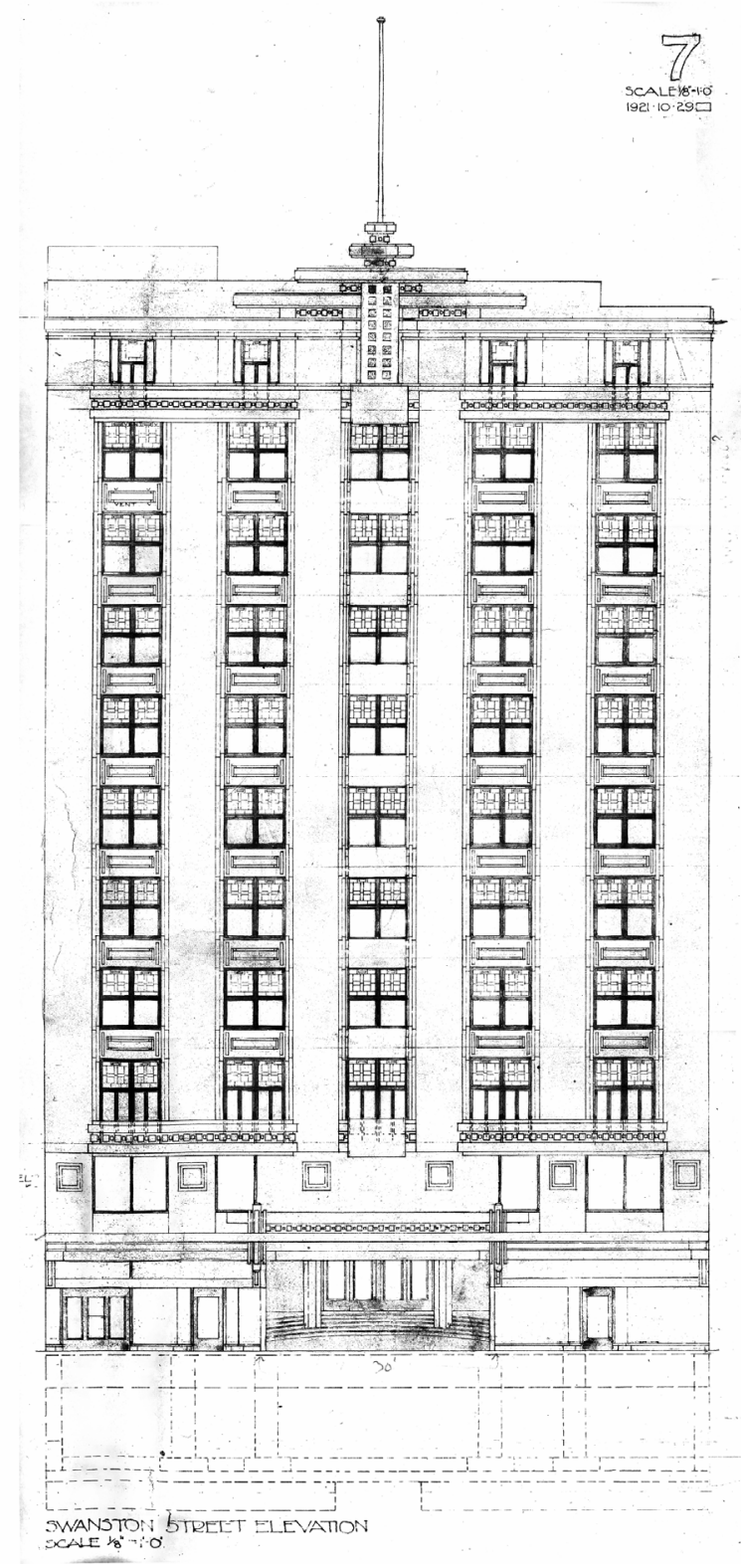

Fig. 4. Permit Drawing 7 (dated 1921.10.29): Swanston Street elevation showing the unbuilt finial and central tribunes. Melbourne University Architectural Collection, State Library of Victoria. Image processing by Keith Lo Bue 
Although pressured by the clients to provide more rentable space, the Griffins succeeded in preserving their canonical ten floors.

The visitor immediately encounters the decad in the ten pairs of electric lights under each side of the awning-fascia at the recently restored main entrance. Their balanced, symmetrical arrangement seems to reflect the old Pythagorean schemata of oblong and square numbers, as do the four-square forms of the fenestration on the main facade. Here the pattern of the glazing is a studied and doubtless symbolic ${ }^{26}$ composition of double, triple and quadruple groupings unified by a single, central cross that is highlighted by its own distinctive glass (Fig. 4). This closewrought mandala alludes, perhaps, to a Christianised form of Pythagoreanism-the Griffins were both deeply, though not conventionally, religious. Much of the Pythagorean system and symbolism had long since been adopted by the Church.

\section{Harmonics of the Capitol}

Given the prominence of the tetraktys and the decad in the exterior and interior of the Capitol, one would expect to find further evidence of architectural design based on the first four integers and their proportional or harmonic relationships. The first space entered at the Swanston Street level is a square area with a stepped ceiling, its walls decorated with square and cubical forms. The original ticket box here was decorated with square shapes too, which are also found in the foyer columns, the windows of the main facade and so on [Turnbull and Navaretti 1998, 197]. Detail Sheet 142 [ANL], entitled "Plan of Verandah Ceiling Reflected," last dated 9 May 1923, shows a design made up entirely of squares of various sizes. The proportion of the square and the cube is 1:1 which defines the most consonant musical harmony, the unison.

The proportion of the double square, another prominent motif of the Capitol, is 1:2 which is the ratio of the next important consonance, the octave or diapason. This ratio also determines the cross - the cosmic symbol that is prominently exhibited on the main facade-as well as the quadrangular subdivision or quartering of the cube. It is the same octave proportion that generates the frieze of alternate larger and smaller cubes raised on the street awning, tribunes etc., of the facade and inside the building.

The frontage of the Capitol on Swanston Street is just over 86 feet wide and the building reaches 132 feet, the maximum height then allowed in Melbourne. Thus the main facade has the form of a rectangle whose width is approximately two thirds of its height. In musical terms, 2:3 is the proportion of the fifth which the Greeks called diapente, the second of the harmonies represented by the tetraktys. It could be objected that this proportioning of the facade is accidental, a natural result of filling the site to the maximum possible width and allowable height; but it is interesting to find that the vertical dimension of 129 feet, which would give a perfect ratio of 2:3 runs from the Swanston Street level to the first moulding above the windows of the tenth floor (Fig. 4). Since the moulding is an arbitrary embellishment, this "sectioning" or "tuning" of the facade would appear to have been deliberate.

The diapente was also apparently the original proportion of the proposed tribunes at the central bay of the second and tenth floors. Sheet 7 of the permit drawings does not specify their dimensions but, according to the scale, they appear to have been 7 feet 6 inches wide by 5 feet high. The unusual height of the fascia, which extends below the floor-line, surely indicates another deliberate "tuning," presumably to obtain the proportion of 2:3. The same module was proposed for the door openings at the Boudoir Foyer level (Fig. 4). ${ }^{27}$ The elevation of the central second-floor tribune or balcony was very carefully considered, and-it must be admitted-the 
various proportions essayed were not all harmonic. Nonetheless, the position and prominence of the rejected tribunes at the notional or spiritual "entrance" suggests that they had some special significance: they might once have been another key to the building and its secret harmonies. Similarly, there was above the main entrance to the theatre auditorium a wall painting with a mythological figure holding a string instrument - the traditional symbol of Apollo, god of health, reason and intellectual music. ${ }^{28}$

Permit Drawing 7 also shows the unbuilt crowning finial, with its four levels separated by rows of large cubes whose numbers 2, 3, 4, 8 may have been an allusion to Plato's lambda series: 1, 2, 3, 4, 8, 9, 27 (Timaeus 35a-36b). This series defines the second tetraktys of Theon of Smyrna $[1979,62-3]$. The first number of the series, 1, could conjecturally be read in above, at the foot of the "flagpole" (Fig. 4); and, while the sixth number, 9, is not made architecturally explicit either, its double, 18, is the number of the large cubes in the moulded frieze above the outer pairs of the ninth-floor windows! Given the distinct possibility that these mouldings have numerological or metaphysical significance, one might speculate on the import of the seven large cubes partially hidden (or at least suggested) by the central tribune of the tenth floor (Fig. 4).

Another striking detail of the unbuilt pediment was the central array of eight pairs of superimposed cubes (Fig. 4). Could this unusual ladder-like motif have been a symbol of the diatonic scale? ("Scale" is derived from scala, the Italian word for "ladder.") And is it just an accident that the harmonically critical moulding above the top row of windows was to cut across this "scale" at precisely the fourth step-the upper limit of the Greek tetrachord? Pythagoras was credited with extending the old tetrachordal or four-note system to the octave scale used today [Nichomachus 1994, 73ff] and both he and Plato considered the study of music to be an essential step to higher learning and wisdom.

Permit Drawing 7 [VSL] shows the two tenth-floor balconies or tribunes which were built, symbolising perhaps the degree of enlightenment and breadth of outlook achieved by those who have graduated from the study of the decad and are about to ascend to the higher learning. Griffin's plans for the universities at Canberra and Sydney reveal that he was fully aware of the old analogy between the hierarchy of academic studies and the form of the buildings which housed them.

At the tenth level and beyond, the Capitol was to have been redolent with esoteric forms and symbolism but nearly all of this detail was ruthlessly cut to make the final structure fit the existing height limitation. Since that restriction no longer applies, there would surely be a strong case now for completing the facade of the redeveloped Capitol House in accordance with the designers' original intentions.

The dimensions of the facade plan on Permit Drawing 3 are particularly interesting. Seeking a balanced pattern of columns and fenestration, the architects created a rhythm of six solid spaces separated by five voids - not an easy pattern to obtain from a regular division of the given site width. Their solution was ingenious: having divided the street frontage into five modules of 16 feet 11 inches, they made the columns or pilasters 6 feet wide and the intervening windows 8 feet wide, while filling up the remaining space with frames and mouldings which are separately dimensioned.

The designers thus imposed on the facade a perceived rhythm of solid to void in the proportion of $6: 8$. This is equivalent to $3: 4$, the ratio that defines the musical interval of the fourth. The Pythagoreans called it diatessaron, the third of the fundamental consonances encoded 
in the tetraktys. That the Griffins were concerned here to establish another symmetry of wholenumber ratios, even when the actual dimensions do not strictly add up, seems to be confirmed by their separate notation of the "ideal" and the "left-over" measurements (Fig. 7). Since the intercolumnar space is $10 \mathrm{feet}$, the principal rhythm of the facade is 6:8:10 (the equivalent of 3:4:5). Thus the facade was to be exactly "tuned" to a Pythagorean "arithmetic proportion," the window-width of 8 feet being the "mean" between the "extremes" of solid and void (6 and 10 feet).

In the plan of the Capitol there is an approximate ratio of 4:5 in the relationship between the width of the foyer (and second-floor Balconette above) and the main street frontage (Fig. 7). The two versions of Permit Drawing 4 (dated respectively 1921.11.25 and 1921.11.30) show numerous revisions of these dimensions-again indicating a careful consideration of the proportions - but the actual dimensions are not far off the ratio of 68:85 or 4:5 which defines the perfect major third. The third, usually a flexible harmony, is certainly suggested by the division of the principal street frontage and its offices into five bays and of the foyer area into four corresponding bays. The bay on the north-eastern end of the foyer (accommodating the stairway to the Balconette) had to be slightly narrower than its matching office space, because of the irregular site.

Not all the proportions of the Capitol, however, can be expressed in simple whole numbers. Even the most ingenious Pythagoreans have had to contend with tunings that generate a left-over or undersized semitone which they called a leimma. Such anomalies are unavoidable in music and architecture-hence the need for pragmatic "tempering" or small, arbitrary adjustments to preserve the general pattern. Irrational magnitudes are unavoidable in any system of whole numbers - as is shown, for instance, by "Pythagoras's Theorem"-and similar problems arise in music when pitch and rhythm are notated on a grid involving the same integers.

The mathematical simplicity of the grid disregards the fact that pitch and rhythm in practice regularly depart from the strict whole-number divisions or modules of musical theory. However, the convenience of working in simple numbers is such that, in architecture, music and most trades and handicrafts, it has been the practice since time immemorial to ignore the small fractions left over, just as "rounding-off" to the nearest whole number has a long-established and perfectly respectable usage in science. On the copy of Permit Drawing 4 dated 1921.11.25 there is a pencilled addition of site-depth dimensions giving a total of 225 feet 8 (and a half) inches, which is rounded off to 226 feet. Such approximations indicate that the actual dimensions of the Capitol can be interpreted with a certain latitude.

Two copies of Detail Sheet 255 contain important clues to the proportioning of the theatre auditorium. The drawings indicate a grid of 4 feet 5 inches square, which is almost the same size as the basic square of the main facade fenestration ( 4 feet by 4 feet). The grid was apparently established by dividing the width of the auditorium space (notionally) into 15 equal parts, which make a total of 66 feet 3 inches. It also appears that the module of 4 feet 5 inches was then applied to the main axis of the auditorium and stage area, giving it a total (notional) depth of 31 modules, which are all meticulously dimensioned on the same sheet (Fig. 5). In theory this arrangement would yield an approximate but not perfect octave proportion-the true octave having the ratio of 1:2. Clearly, however, the general plan of this area is a double square, whose overall dimensions are shown on Permit Drawing 4 as 69'10" x $136^{\prime} 81 / 2^{\prime \prime}$. 


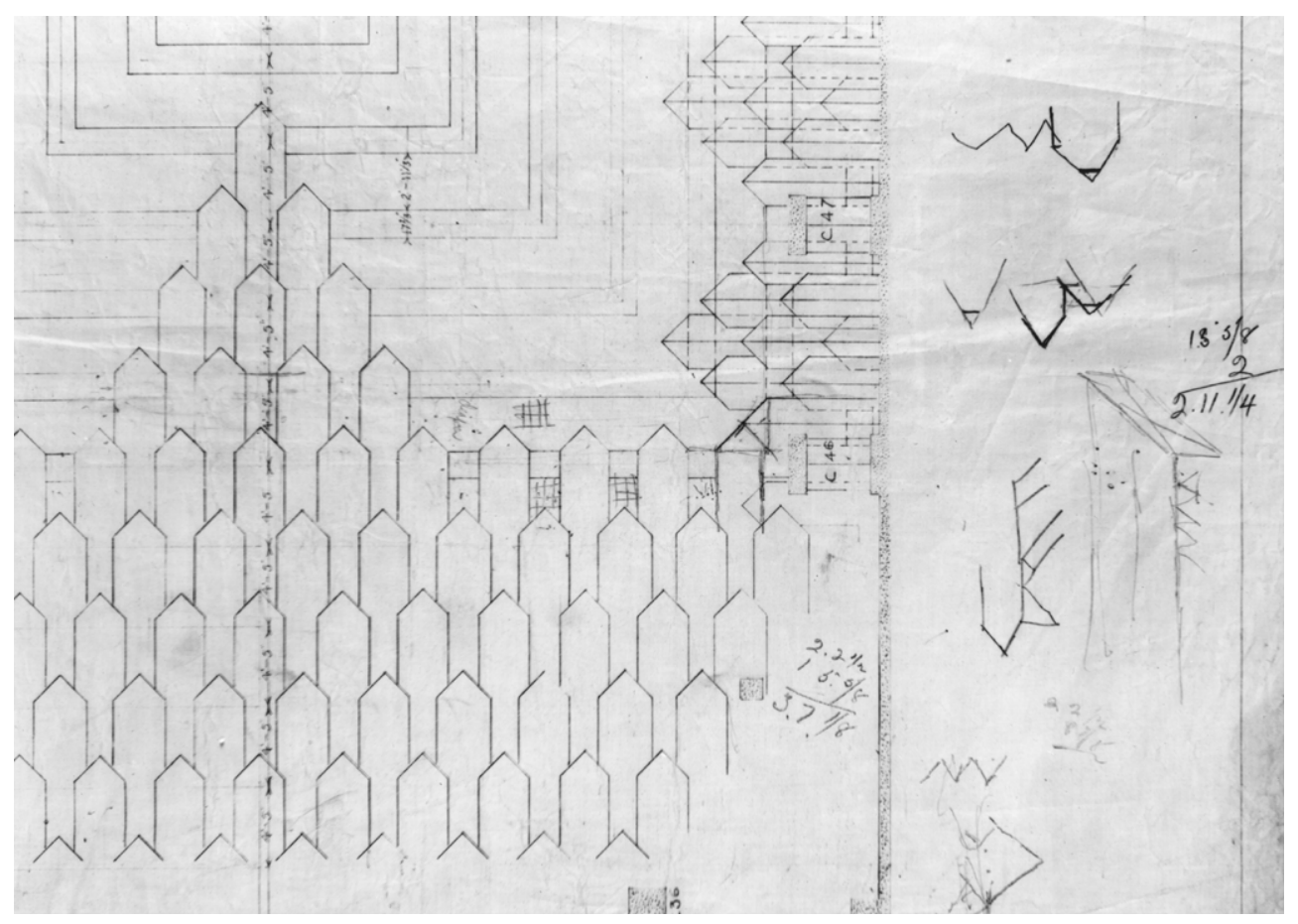

Fig. 5. Part of Detail Sheet 255 (last dated 1923.7.18): Plan of Main Ceiling (with marginalia) showing proposed tetraktys forms of proscenium and side wall. Melbourne University Architectural Collection, State Library of Victoria

Since the square and double square are such prominent motifs of the Capitol, the question arises as to whether this irregularity in the plan of the auditorium and stage area was arbitrary. Given that the restrictions on the depth of the auditorium were much less pressing than those on the width, the issue of whether the deviation from exact squareness was deliberate or not is far from trivial. We suspect that it was not entirely due to site or other design constraints. ${ }^{29}$

Our analysis reveals that the Capitol embodies the simple harmonic proportions-1:1, 1:2, 2:3, 3:4 and 4:5-or their close approximations. The first four ratios, those encoded in the tetraktys, have always defined the structural intervals of the pure or untempered diatonic scale and the last ratio defines the perfect major third, the newly-tolerated consonance that marks the advent of modern harmony and polyphony during the Renaissance. So, as well as alluding to the forms of the ziggurat, stupa, Greek temple and Gothic cathedral, the Capitol seemingly acknowledges and extends the ancient tradition of harmonic proportion ${ }^{30}$ or "frozen music" in being organised and embellished according to the whole number ratios of the musical scale or near approximations. To complete our case we must return to the architects' own testimony. 

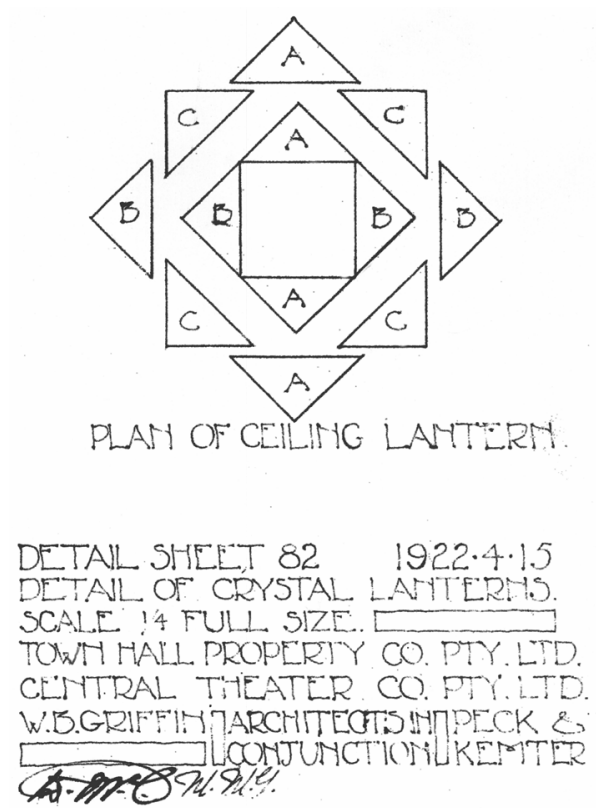

Fig. 6. Part of Detail Sheet 82 (dated 1922.4.15): Plan of Ceiling Lantern. Melbourne University Architectural Collection, State Library of Victoria

\section{Music in the Griffins' World-View and Philosophy of Design}

As far as we know, the Griffins never acknowledged Pythagoras explicitly, even though they adopted and adapted much of the system traditionally associated with his name. Among disciples of the esoteric arts, such reticence is not unusual.

Addressing students at Sydney University in a 1924 lecture entitled "The Architect's Burden," Walter declared: "When we come to think of it, no art has nor merits in our day so great popular appeal as music..." [Griffin 1940-49, III: 89]. Although the extent of their knowledge is not known, the Griffins were seriously interested in music and both took an active part in musical and dramatic performances by the bohemian community they established at Castlecrag, on Sydney's Middle Harbour: "The finest musical talent of Sydney and many visiting artists came and sung and played for us. And many a one on leaving has said, "I'll be glad to come any time you want me Mrs. Griffin” [Griffin 1940-49, III: 291, III: 380ff].

Their available statements on the subject leave no doubt that both of them were well informed musically, as well as being exceptionally aware of its cultural importance and philosophical relevance - not just to the aesthetics of architecture and design, but also to the grand matters of cosmology, education and morality. In his 1914 proposal for the central town square of Leeton, New South Wales, Walter imagined it with "refreshing shaded promenades, fountain pool and music... Perhaps the good old afternoon band concerts of the Spanish Towns may be revived here where the environment as well as the temperament of the people are so well suited" [Griffin 194049, III: 323].

Their taste was broad, enlightened and progressive. Writing of the "Theatre Magnificent" in 1934, the Griffins (or, more likely, just Marion) proudly recorded that "In music we have 
submitted every kind, from Symphonic, Classical, Operatic and, at the present time, are featuring the trend in music towards modernism" [Griffin 1940-49, II: 31c-32b].

In a letter dated 31 December 1935, Walter wrote to his wife from Lucknow saying how he had "got real satisfaction out of the American light opera Naughty Marietta of Victor Herbert's old fashioned music." [Griffin 1940-49, I: 61]. Writing to Walter from Castlecrag on 9 January 1936, Marion described a rehearsal she had attended two days earlier in the recording studio for the radio broadcast of Der Rosenkavalier by the Australian Broadcasting Commission, commenting that it "outfutured the futurists." [Griffin 1940-49, I: 62].

Soon after, on 31 March 1936, Marion wrote to Walter again, reporting on what was probably a rehearsal of the farewell recital at the Sydney Town Hall of the gifted young soprano Joan Hammond ("another Melba") who was proceeding to study in Vienna. Her accompanist was an anthroposophist and close friend of Marion's, Lute Drummond, who "played superbly, the most perfect accompanist I ever heard except perhaps the leader of the Boston symphony orchestra... She and Joan were as one. It is all like a wonderful fairy story" [Griffin 1940-90, I: 92a].

Marion herself played the piano and considered her sister a "very fine performer" [Griffin 1940-46, IV: 100]. She was also passionate about musical education for the young. ${ }^{31}$ Friends were aware of "the fact that I thought I had the promise of being a musician in my next life so in this incarnation I was fulfilling a number of things Steiner says may be prerequisites. I am an architect, working with form, also in mural decoration, have mathematical talent, have worked with music no matter with how little effective results..." [Griffin 1940-49, I: 157]. ${ }^{2}$

In an essay entitled "The Bungalow Indoors," Marion explained the importance of harmony in interior design and the need to avoid the unpleasant effects of "discordant visual notes":

We understand this harmony and discord in music. In the course of the centuries it finally dawned on us that there was a law in accordance with which sounds were pleasing or displeasing to us. We studied into the nature of the law and then we entered into the great, new, limitless world of music - a heaven of measureless delights.

A building is line, form, motive [sic], and until we realize that they must be used in conformity to law to be pleasing we will get occasional satisfying results but not great or growing architecture, and as all things act and react on each other so the very development of our character-our souls, is dependent on these laws of nature which are spiritual as well as physical in themselves and in their effects [Griffin $1912,118]$.

The analogy of music and architecture was again invoked by Walter in his proposals for Newman College, Melbourne:

Aesthetic Considerations. As the art of music is based on consciousness through the conservation of sound waves and emphasis through rhythm, so architecture is concerned with consciousness of the only other reality of which physical beings are cognisant in the preservation of the sense of space by its conservation and emphasis. 33

He developed similar themes in an undated lecture on "Architecture" which his wife preserved in The Magic of America: 


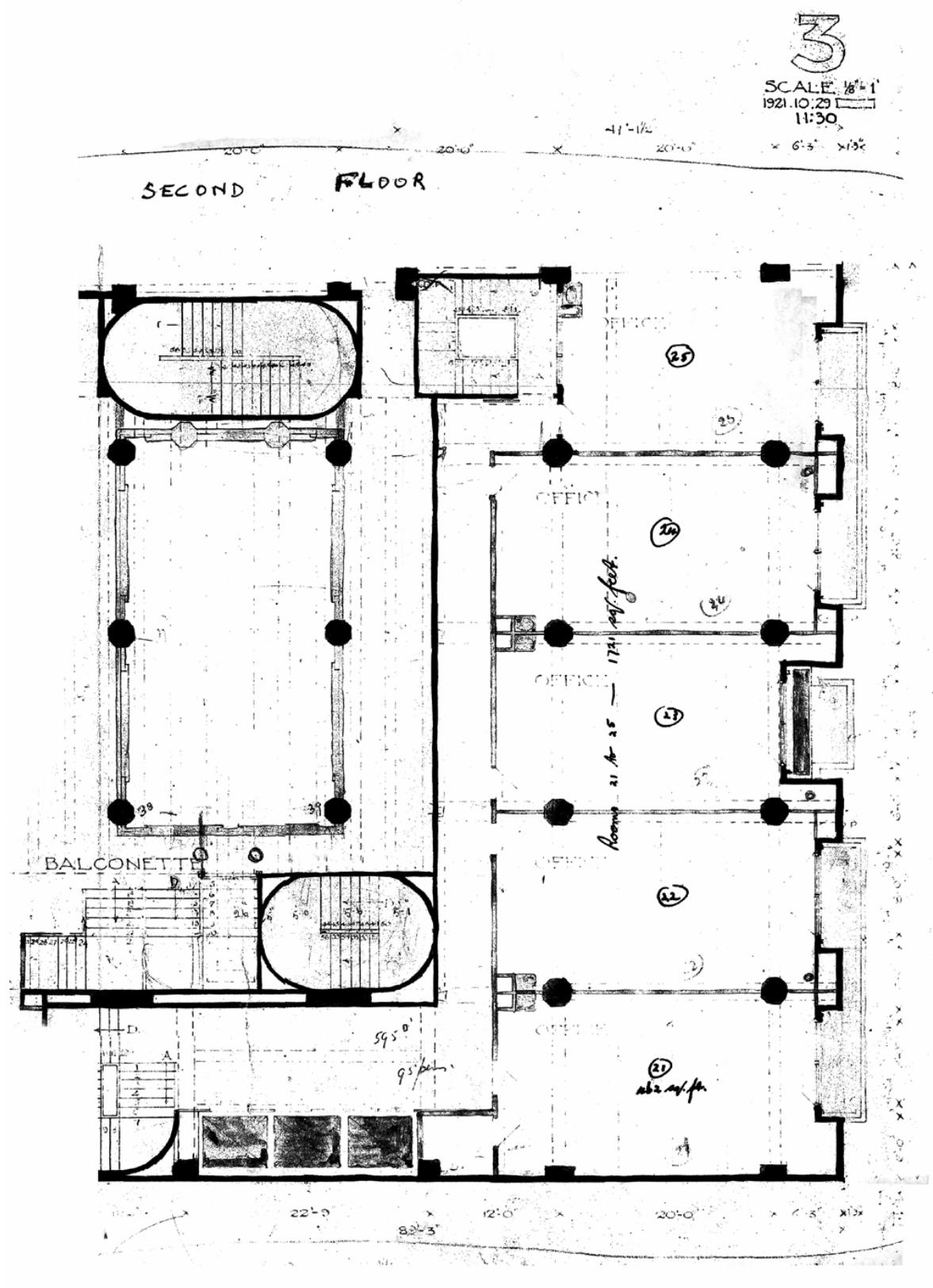

Fig. 7. Part of Permit Drawing 3 (last dated 1921.11.30) showing plan of second floor offices and Balconette. Melbourne University Architectural Collection, State Library of Victoria. Image processing by Keith Lo Bue 


\begin{abstract}
... Human beings in all stages of development have taken satisfaction in music as distinguished from noise but the development of this wonderful field was very limited till the law-a purely mathematical one-of the conservation of rhythm — was understood. When we learned that noise resulted from the interference of sound waves with each other and the consequent destruction of sound and that the sounds we derived pleasure from were such combinations as reinforced each other so that they went on to infinity, immediately there began a development of the art of music which is one of the miracles of the present time. A hundred years has [sic] done what all the thousands of years preceding did not begin to do. There is a great moral lesson in this. Let us try to learn this fundamental lesson and in whatever we are doing search out the controlling law.
\end{abstract}

Music is a time art measured by rhythm. To satisfy the human soul those units must be preserved and must be so used as to reinforce each other, for destruction is painful to us but evidence of continuity are $[s i c]$ a joy and inspiration. Architecture is a space art. Let us search out the basic law. It is not the conservation of space. As in music we rejoice in being made conscious of time, one of the great fundamental elements in our present creation, and in being made aware of infinity through the preservation of rhythm, so in architecture and landscape architecture which are but interdependent elements of one field, we rejoice in being made conscious of space and can be satisfied only when the space units we use reinforce each other and a feeling of spaciousness is obtained. In a building or in a community a huddle and clutter of unrelated units is as distressing as a harsh sound...

As in the time of art [recte, art of time], the bringing together of sounds does not constitute the making of music, so in Town Planning and the sub-division of space into units cannot be considered as anything but noise, and is not Town Planning at all until these units have all been brought together into harmonious relation to each other, and the law of conservation of space observed as in music the sound wave must be conserved [Griffin 1940-49, IV: 176-181].34

So, when the Griffins talk of their aim to "harmonize art with nature" [Griffin 1940-49, III: 210-211], they are not always speaking vaguely or metaphorically: sometimes, at least, they are alluding to the traditional analogy of music and architecture-that is, to the common employment in these arts of whole-number ratios and modules based on the simpler harmonic proportions. In this respect, their use of "harmony" and similar terms is more deliberately musical and specifically mathematical than that of conventional theory and criticism-as, for example, when Walter uses the terms "consonance," harmonious", and "harmonize" (twice) in half a page [Griffin 1940-49, II: 36b].

Something of the Griffins' esoteric notions of harmony in nature was caught by their disciple William Harte Smith in his threnody entitled "Castlecrag":

\author{
He builds with inspiration sought \\ in wind-carved rook, in color caught \\ from nature, octaves of her three \\ in unobtrusive harmony... \\ [Griffin 1940-49, I: 207].
}

Elsewhere Walter asserts, "In fact, a color scheme can hardly be called a scheme unless it contains 3 tones just as 3 tones are required to form a chord in music" [Griffin 1940-49, IV: 120]. Thus his talk of "harmonizing" the tones of colour is natural and appropriate [Griffin 194049, IV: 128]. The public unanimity of the partnership, however, makes it difficult to assign individual responsibility for these shared ideas - though we suspect that Marion was often the driving force in this department. She seemingly enjoys priority of publication as well as preserving the final and most explicit expositions of their musical philosophy in The Magic of America. In a short essay entitled "Casa Bonita" (the house at Castlecrag designed by Walter and occupied by Marion after her return from India), she describes their favourite Castlecrag house as "a note of 
emphasis in a natural setting taking its place harmoniously, a note in a melody, a chord in a harmony" [Griffin 1940-49, III: 309]. Thus their Castlecrag architecture in general "has struck a distinct bold note in Australia...in harmony with the great amphitheatre of stone and forest" [Griffin 1940-49, II: 399]. ${ }^{35}$

Walter once declared that "Nature demands a unity in her ideal which embraces human nature and its expressions as well as all animals, vegetables and inanimate creations, and requires of each a contribution that shall fit into the great harmony"-another unmistakable allusion to the old Pythagorean world-view and its derivative, the "Great Chain of Being" [Griffin 1940-49, IV: 34].

Discussing their last Australian work, the Pyrmont Incinerator (Sydney, 1934-6), Marion claimed that "In the basic arts of architecture (in its broadest sense) and music (which is now making one with speech and motion) Australia is now ready to lead the world." 36 This same synthetic or synoptic view of music and architecture pervades her rapturous eulogy of the Capitol Theatre:

The lofty fretted ceiling glows and pulsates with all the splendor of the Aurora, amid the mystic architectural forms of this theatre magnificent slowly dawns on the observers the daring conception of the designer - a picture playhouse where music, form and color conspire in a complete captivation of the senses [Griffin 1940-49, II: 32b]. ${ }^{37}$

In the eyes of its creators, the Capitol Theatre was to be not only a "National Institution... for the citizens of Melbourne and Australia" [Griffin 1940-49, II: 31c], but also a veritable Gesamtkunstwerk (Total Art-Work) 38 _one of "mysterious loveliness and a powerful grandeur" [Griffin 1940-49, II: 28e]. These observations on the theatre (compiled in the 1940s from materials of various dates, mostly-if not entirely-written by the Griffins themselves) are a primary source of the architects' intentions; but the essay would acquire a different emphasis and a very particular significance if, as has been claimed, ${ }^{39}$ Marion herself was principally responsible for the design of the auditorium ceiling:

A Color Symphony-The magnificent roof span of the theatre gave the designer full range for a fanciful effect, and audiences find their attention captured by the unique design of the walls and ceiling... The ceiling itself, over the central stalls, breaks up into a great height in serrated lines of fretted plaster, all broken into little cubicals [sic] upon which thousands of unseen globes pour artificial light in a myriad of varied hues. The light effects are changeable at a touch and a skilled operator is able to play them like a color symphony.

One gets an impression similar to that received when watching that chemical myracle [sic] of the formation of crystals... [Griffin 1940-49, II: 33b]. ${ }^{40}$

Her discussion of the Capitol concludes with a revelatory statement that trails off in the author's manuscript addendum:

Since the whole of the material world is made up from the battle between light and soundthe form-building forces-these two can touch all the strings of human nature for the temperaments too-choleric, sanguine, phlegmatic and melancholic are determined by a preponderance of one or another of these forces [continues in $\mathrm{ms}$ ], red, yellow, blue, lilaccreating warmth, light, sound and magnetism-heat, gas, liquid \& solid conditions of matter [Griffin 1940-49, II: 38; cf. III: 399b, 427]. ${ }^{41}$ 
This is her mature anthroposophical reformulation of the ancient macrocosm-microcosm analogy and the associated doctrines of Pythagorean psychology and humoural medicine that are symbolised in the form of the Capitol's proscenium lanterns and several other Griffin designs. The earliest known Greek exponent of the quaternary paradigms usually associated with the physician Hippocrates of Cos was his predecessor Alcmaeon of Croton, who was probably a younger follower of Pythagoras.

In her lecture "Trees," delivered at the Armstrong School in Chicago (c.1931-2), Marion offers another insight into the genealogy of her Pythagoreanism. During a frankly mythic presentation, charmingly adapted to her young audience, she refers to the "music of the spheres" and its origin in natural rhythm or vibration [Griffin 1940-49, IV: 341]. Despite the fairy-tale mode of exposition - and the prominence of the fairies themselves - this is a highly significant allusion to the central doctrine of the Pythagorean school. Her picturesque statement represents a serious and systematic philosophy that draws on contemporary physics and anthroposophy as well as the venerable traditions of harmonic cosmology. 42

\section{Conclusion}

The evidence indicates that, by the 1920s (if not earlier), the Griffins had adopted a covert Pythagorean ideology and attempted, at least with the Capitol, to develop a new synthesis of musical and architectural aesthetics. We do not know how far-or for how long-they deliberately employed the harmonies and dissonances of musical proportion in their architecture and landscape design but the following statement by Walter is of crucial importance:

In Town Planning as in Architecture there must be a vision. There must be a scheme the mind can grasp, and it must be expressed in the simplest terms possible. Just as music depends on simple mathematical relations so do Architecture and Town Planning [Griffin 1940-49, I: 361g]

Similarly, in an essay by Marion entitled "The Japanese Type," Le Corbusier's work is condemned as mere engineering: "It lacks the spirit of mathematics, the spirit of music" [Griffin 1940-49, IV: 215].

One could hardly formulate a more concise summary of our central argument. Here Walter unambiguously reaffirms the old harmonic analogy between the urban microcosm and its constituent architecture - a relationship still occasionally sensed in the affinity between the private cortile and the public piazza. The harmonic conception of urban form-a Vitruvian commonplace during the Renaissance-remains explicit in the naming of the two principal squares of Athens: Syntagma (usually translated as "constitution", was primarily the ancient Greek term for a scale or musical system) and Omonia (the modern Greek equivalent of "harmonia"). The mathematics of musical tuning and temperament, as Ernest G. McClain has demonstrated, pervades the cosmology as well as the town-planning allegories and social engineering of the "Pythagorean Plato"-like his master, a devout admirer of things Egyptian.

All of these conceptions are predicated on the age-old "analogy of the macrocosm and the microcosm," that comprehensive rationale of the natural world and the role therein of human art, which (despite its familiar Greek formulation) has antecedents older than civilisation itself. Perhaps the most ancient, certainly the most widely diffused, world-picture, this image long antedated the art of permanent building, particularly in the astral dance of prehistoric cultures. ${ }^{43}$ 
Bathed in these perennial resonances and bedecked with the outward symbols of its inner harmonies, the Capitol is Australia's greatest Pythagorean edifice. The Crystal Tetraktys-a stunningly original creation-is the key to this unique secular temple, one of the two most important buildings to survive of the Griffins' work in Australia. 44

\section{Acknowledgments}

For helpful advice, many thanks to Donald Leslie Johnson (Kangarilla, S.A.), Peter Y. Navaretti (RMIT University, Melbourne), Robyn Oswald-Jacobs (RMIT University), Craig Allchin (Six Degrees Pty Ltd), Judith Wells (University of Newcastle, NSW), Craig Cahill (Manager of the Capitol Theatre) and Anthony Rainer (Melbourne).

This essay is dedicated in gratitude to Peter Proudfoot-friend, mentor and disputant of almost fifty years.

\section{Notes}

1. See "Capitol Theatre", The Age (Melbourne), 8 November 1924, 20: "Artistic orchestral and organ effects accompanied the screening." See also The Sun 8 November 1924, 15. One wonders to what extent the Griffins were involved in the conception of this dramatic presentation. The organ was WurliTzer's Opus 637, a style 260 instrument, with three manuals and 15 ranks of pipes. (I am advised by Mr John Wolfe of the Theatre Historical Society that "WurliTzer", with the capital "T", was the original trademark). For more details see http://www.caths.org.au/capitol.htm.

2. An exception was the comment in Table Talk: "The illumination of the theatre is by concealed lights in this roof and the effect, when they are slowly changed from one prismatic color to another, is very beautiful and romantic. But it is most beautiful of all when the lights are pure white, unshaded, for then they seem to give to the great moulded beams and blocks a translucence that makes them appear semi-transparent alabaster" (13 November, 1924, 18). The Griffins were probably the source of this as well as the article "Wizardry of Lighting," Herald Special Supplement (Melbourne), 7 November, 1924, 1. None of the newspapers managed to publish a full and accurate account of the opening event, even though there was a printed programme.

3. According to Lucian (second century A.D.), the Pythagoreans also called the tetraktys "the first principle of health" [Huffman 1993, 356].

4. According to Theon of Smyrna, "The importance of the quaternary obtained by addition (that is to say $1+2+3+4$ ) is great in music because all the consonances are found in it. But it is not only for this reason that all Pythagoreans hold it in highest esteem: it is also because it seems to outline the entire nature of the universe" [K.S. Guthrie 1987, App. I: 317]. Since the original edition of this collection appeared c.1919 - 20, it may well have been seen by the Griffins.

5. Timaeus begins with "One, two, three..." as Socrates counts through the primary numbers of the decad that generates the Pythagorean world [McClain 1978, 57]. Another important source of Pythagorean tradition is Theon of Smyrna (early second century AD) [1979, especially $62 \mathrm{ff}$.$] .$

6. That is, no whole number falling within the decad $1-10$. The ratio of 19:20 approximates to the Pythagorean diatonic semitone of 243:256.

7. "Architecture has been well expressed in the well known dictum-that architecture is frozen music. The corollary that music is molten architecture provides the best possible index to the nature of the musical art which is to come" [Griffin 1940 - 49, I: 155-6]. 
8. Although Lethaby wrote a chapter on "The Planetary Spheres" [1891], he carefully avoided the Pythagorean theory of world harmony. Chapter XI "The Windows of Heaven and Three Hundred and Sixty Days" [Lethaby 1891] completely misses the musical significance of the number 360. Cf. [McClain 1978, 25ff].

9. Though the writings of Claude Bragdon often seem to anticipate or echo the architecture and ideology of the Griffins, we have not found any evidence of personal contact.

10. Walter Griffin had already contributed signed articles to this magazine. The Griffins were obviously responsible for the article from Australian Home Beautiful quoted in [Griffin 1940-49, III: 307-8).

11. Walter Burley Griffin, Capitol Theatre and Capitol House. Melbourne University Architectural Collection. State Library of Victoria, WD.THE.32. We thank the staff of the Pictures Library for their courteous and efficient assistance. Several more original Capitol drawings are held by National Library of Australia, Donald Leslie Johnson Collection of Walter and Marion Griffin Documents, MS 7817, Box 22 (v).

12. It was evidently Marion Griffin who wrote that "one gets the impression similar to that received when watching that chemical miracle of the formation of crystals except that a particularly appropriate form has been decided on and fixed in concrete form" [Anon. 1934]. The Griffin authorship is confirmed by the American spellings and the inclusion of a longer version of the text in [Griffin 1940-49, II: 28-37]. "When the theatre was being planned [Walter] Griffin said to the owners- "What a marvellous thing it would be if we could build a theatre in a crystal cave" [Griffin 1940-49, III: 277]. The Minutes of the Directors' Meeting of the Central Theatre Company Pty. Ltd., 16 December 1921, note that the "advisibility [ sic] of purchasing crystal lamps as against importing raw material \& manufacturing the same here was discussed but the matter was left in abeyance." This appears to be the first dated reference to the crystalline decoration of the theatre auditorium [VSL, Ms 3379 (1), 82].

13. [Turnbull and Navaretti 1998, 52-3]. Perhaps there is a hint in this symbolism that modern commerce must now provide a way to the higher spirituality.

14. The horizontal discrepancy, which is also apparent in the photograph reproduced in [Turnbull and Navaretti 1998, 197], has eluded even skilled draughtsmen, as in the sketch on the title-page of Capitol Theatre [Grodski et al.1989]. The illusion is perfect when the building is viewed at an acute angle as, for example, from the traffic lights across the road at the junction of Swanston and Little Collins Streets.

15. The narthex was traditionally reserved for women; the upper level of the corresponding space of the Capitol is the Boudoir Foyer Level.

16. The transverse section closely resembles that of Norman Bel Geddes's "Theatre Number Six," which was designed for a site similar to that of the Capitol. See the illustration in [Bragdon 1922, 173]. The Griffins were familiar with Geddes' work.

17. According to Iamblichus, "Pythagoras is said to have been the first to call himself a philosopher...He likened the entrance of men into the present life to the progression of a crowd to some public spectacle. There assemble men of all descriptions and views. One hastens to sell his wares for money and gain; another exhibits his bodily strength for renown; but the most liberal assemble to observe the landscape, the beautiful works of art, the specimens of valor, and the customary literary productions. So also in the present life men of manifold pursuits are assembled. Some are influenced by the desire of riches and luxury; others, by the love of power and dominion, or by insane ambition for glory. But the purest and most genuine character is that of the man who devotes himself to the contemplation of the most beautiful things, and he may properly be called a philosopher" 
[K.S. Guthrie 1987, 70]. For a similar Pythagorean conception of the theatre as a temple of education, see [Bragdon 1925].

18. "Commencing with The Ten Commandments, the Capitol Theatre began its history in a blaze of glory" [Griffin 1940-49, II: 31c].

19. “... it is now our task to bring about the ascent into spirit" [Griffin 1940-49, IV: 395].

20. Cf. [Wachsmuth 1932, I: 38ff]. Marion, who read German fluently, quite possibly saw the original edition which was published in 1923.

21. Cf. the photograph of what was actually built [Turnbull and Navaretti 1998, 190]. The majestic crescendo might be compared to the processional symphony of Handel's coronation anthem, Zadok the Priest.

22. "The sound or chemical ether creates the crescent, the wave form. It is the force that brings liquidity into existence. We catch the connection of liquidity to sound in the wave movement which sound sets up and in the great increase of sounds in liquids. The wave form we see in the restless seas..." [Griffin 1940-49, III: 425 (reel 2)].

23. The Griffins' version of the Greek system is briefly elaborated in the essay entitled "Blue Mountains. Katoomba" [Griffin 1940-49, III: 399b]. "The 4 which we experience today are warmth, light, sound and life" [Griffin 1940-49, III: 427].

24. According to Theon of Smyrna, these elements are symbolised by the constituent numbers of the tetraktys: 1=Fire; 2=Air; 3=Water; 4=Earth [K.S. Guthrie 1987, 318]. The Griffins accepted this system (Asiatic in origin) as the source of the four creative spiritual forces or ethers: "Australia is not to be understood unless you understand Greek Science with its classification of earthly things into 4 elements..." [Griffin 1940-49, III: 399b].

25. "Griffin was actively involved in specific philosophical pursuits all his life and it is most likely that he made symbolic references to these concepts in his designs" [Muller 1976, 34]. Cf. [Turnbull and Navaretti 1998, 48-9]. Historians have generally overlooked the literary and philosophical context of the Griffins' work in the publications of American Pythagoreanism. For possibly relevant examples, see [Navia 1990, nos. 125, 127, 265, 282, 367, 370, 381, 771].

26. The pattern formed by the glazing bars resembles hieratic forms of the cross: see [Burckhardt 1986, 64].

27. Cf. Howard Robertson's observation that the ancient Greeks "would often make the height in proportion to the width of the temple in some such simple ratio as $2: 3$, and use this ratio in the proportion of other details of the design" [1927, 38].

28. "We know now that the nervous system is a musical instrument and that through music Apollo taught the European peoples to think, not just to remember as ancient peoples did but to think, to rationalize" [Griffin 1940-49, III: 460]. Cf. Marion's praise of her anthroposophical friend Lute Drummond: "She was indeed laying the foundation for the building of a new civilization in Australia through music, as Apollo had done through the regions of eastern and central Europe many centuries ago..." [Griffin 1940-49, IV: 16970].

29. Thanks to Peter Proudfoot for help in interpreting this detail of the plan. Space does not allow us to pursue the question of off-square plans and irregular quadrangles which are found throughout ancient and medieval buildings but rarely in modern architecture. There are several approximate squares in the Capitol, including the proscenium opening, and also other approximate double squares, such as the void between the foyer Balconette and the stalls below. Some of these subtle irregularities could have been introduced as deliberate dissonances to enliven the general harmony. 
30. The use of harmonic proportions in ancient and medieval architecture is still debated. A suggestive study is [Kayser 1958].

31. Hazel, the young daughter of the Stephens of Castlecrag, used to imitate her accent as well as her way of organising childrens' "concerts": "Come on-Attention! March!" [Griffin 1940-49, I: 207-8].

32. "I have good reason to be thankful to Aunt Myra for her continued interest in my musical education in spite of the fact that I had no special talent in that direction. Through her I became acquainted with music and even achieved a foundation which, after an inertia of many years of no practice, enabled me (when the need came for me to forget myself) to practice Beethoven and other composers with sufficient satisfaction to myself to be a great and lasting healing of the soul" [Griffin 1940-49, IV: 146]. In an undated letter (c.1936), Lute Drummond wrote to her in India: "You were laying your plans, counting your chances for being a musician in your next incarnation..." [Griffin 1940-49, I: 154]. Reincarnation and the "cycle of birth" were standard Pythagorean tenets. On the following page she recommends Cecil Gray's "Predicaments, or Music and the Future" as "very interesting indeed especially when dealing with architecture...."

33. This observation is reported in an anonymous review entitled "Unsound Architecture", in the Sydney magazine Building [XXI (March 1918), 64]. No source is given for the quotation which came presumably from the architect's own proposals for Newman College.

34. The error "time of art" occurred in the retyping of this passage from the earlier version (III: 374-7) which mentions the "time art." Marion's caption to a drawing of the Hollister house, claims that Walter's design "spread these harmonies from New York to California" [Griffin 1940-49, IV: 182]. Griffin elsewhere refers to the importance of (spiritual) "concord that could express itself in an environment of harmonious forms" [Griffin 194049, III: 55]. Cf. his reference to the "discordant houses" typical of contemporary society [Griffin 1940-49, III: 64].

35. Referring to the architectural development of decorative motifs, Walter argues, "It is not possible to say that any one degree of elaboration is better than another. Each one is a song. Only to overdevelop one part and neglect another would be as bad as to put the treble of a symphony with the base [ sic] of a finger exercise" [Griffin 1940-49, IV: 333].

36. An optimistic but hardly novel view of the performing arts: the ancient Greeks included poetry and dance in their broad concept of music (mousike techne). Marion was presumably referring to contemporary experiments in neo-classical dance and other arts. She regarded Isadora Duncan as one of the "founders of creative thinking in the arts" [Griffin 1940-49, IV:18].

37. Both the general form of the Capitol and the theatrical use of colour music are strikingly anticipated by Claude Bragdon [1922, $171 \mathrm{ff}$, especially 173, 182]. Though the design of the auditorium ceiling was well advanced by the time this article appeared, it could have influenced some of the detailing produced subsequently: for example, of Detail Sheets 230 and 240 (dating from May 1923).

38. Recalling the festivities of Castlecrag, Marion notes: "Here, as at all the parties, all the arts were represented." [Griffin 1940-49, III: 137]. "The arts are play and they play into each other" [Griffin 1940-49, IV: 252].

39. In a letter to Van Zanten dated September 1965, Roy Lippincott wrote, "She had an almost worshipful regard for his genius...she never attempted to influence his planning... but when it came to detail and pattern she was supreme and he seldom or never suggested

96 GRAHAM PONT - The Cinema as Secular Temple 
any alterations. The outstanding example was the ceiling of the Capitol Theatre in Melbourne" [Johnson 1977, 12-13].

40. The misspellings again point to Marion: she had not only an unbounded enthusiasm for crystals but also a quaint habit of spelling by ear rather than eye-another sign of her musicality. She later describes the ceiling lights as being "played like an angel orchestra" [Griffin 1940-49, III: 57].

41. Marion believed that her own temperament was sanguine [Griffin 1940-49, III: 333; IV: $249 \& 292]$.

42. It is not generally recognised that the Griffins were responsible for some of the first attempts to develop a philosophy of architecture and landscape design appropriate to Australia. Thus Marion has a strong claim to be considered Australia's first female philosopher. Pythagoras is remembered for his radical innovation of admitting and encouraging female disciples [Meunier 1980].

43. As, for example, in the figure of Urania, Muse of Astronomy, dancing in the train of Apollo [Sachs 1937, 124ff]. On the ancient connections between geometry and ritual (and with profound implications for the prehistory of mathematics in all the performing arts), see the suggestive articles of Abraham Seidenberg [1962, 1981, etc.]. Some of his insights are independently confirmed, as well as dramatically illuminated, by Kapila Vatsyayan [1983].

44. The other is Newman College, Melbourne. Given the foregoing argument, one would have to predict that this building too was designed on esoteric principles.

\section{References}

\section{Online Images}

Ian Williams Collection [IWC] (http://www.caths. org.au/capitol.htm). (Images are identified by their website numbers.)

State Library of Victoria [VSL], Pictures Collection. http://www.statelibrary.vic.au/. (Online images are identified by their Library Accession Number). More images of the Capitol are available at other websites, including http://www.rmit.edu.au/browse and http://www.smofbabe.net/du/capitol.html.

\section{Drawings}

State Library of Victoria [VSL], Melbourne University Architectural Collection, Walter Burley Griffin Capitol Theatre and Capitol House, Melbourne, WD.THE.32.

National Library of Australia [ANL], Donald Leslie Johnson Collection of Walter and Marion Griffin Documents, MS 7817, Box 22 (v).

\section{Literature}

ANON. Unsound Architecture. Building [Sydney] XXI (March 1918): 64-69.

ANON. [Marion Mahony Griffin?]. 1934. Modern Alladin's Lamp Reveals The Aurora: The Wizardry of a Symphony in Colors! in E.S. Abbot, E.S. and E.V. Kennebeck, eds., Paramount's Capitol News. Tenth Anniversary Edition. Melbourne: n.p. [Paramount Film Service Ltd.].

BeLL, E.T. 1946. The Magic of Numbers. New York: McGraw-Hill.

BoYD, RoBIN. 1965. Griffin's Magic Glows Again. The Australian, 24 December 1965, 8.

Bragdon, Claude. 1910. The Beautiful Necessity. Rochester NY: Manas Press.

1922. Towards a New Theatre. The Architectural Record LII (September 1922), 171-182.

1925. The Theatre of Tomorrow. Pp. 126-147 in Old Lamps for New: the ancient wisdom in the modern world. New York: Alfred A. Knopf.

BurcKhardt, Titus. 1986. Sacred Art in East and West: Its Principles and Methods. Lord Northbourne, trans. Rpt. Bedfont, Middlesex: Perennial Books.

D’Olivet, Antoine Fabre. 1987. Music Explained as Science and Art. Joscelyn Godwyn, trans. Rochester, VT: Inner Traditions International. 
Fideler, David R. 1987. Introduction to The Pythagorean Sourcebook and Library. Kenneth Sylvan Guthrie, trans. Grand Rapids: Phanes Press.

GODWIn, JosCELYN. 1993. The Harmony of the Spheres. Rochester VT: Inner Traditions International.

GOLDSCHMIDT, ViCTOR. 1901. Ueber Harmonie und Complication. Berlin: Julius Springer.

Griffin, Marion Mahony. 1912. The Bungalow Indoors. Pp. 115-120 in One Hundred Bungalows. Boston: Rogers \& Manson (for the Building Brick Association of America).

. c.1940-49. The Magic of America. New York Historical Society. Microfilm, National Library of Australia, reels G1670-71.

Grodski, Robert, et al.1989. Capitol Theatre. Prahran: Robert Grodski \& Associates Pty. Ltd.

Guthrie, Kenneth Sylvan, trans. 1987. The Pythagorean Sourcebook and Library. Grand Rapids: Phanes Press.

GUTHRIE, W.K.C. 1962. A History of Greek Philosophy. Cambridge: Cambridge University Press.

HaAR, JAmEs. 1973-4. Pythagorean Harmony of the Universe. Pp. $38 \mathrm{ff}$ in vol. IV of Dictionary of the History of Ideas, Philip P. Wiener, ed. New York: Charles Scriber's Sons.

HaAse, Rudolf. 1969. Geschichte des harmonikalen Pythagoreismus. Vienna: Elizabeth Lafite.

Heninger, S.K., Jr. 1977. The Cosmographical Glass. San Marino, CA: Huntington Library.

Huffman, Carl A. 1993. Philolaus of Croton. Cambridge: Cambridge University Press.

Johnson, Donald Leslie. 1977. The Architecture of Walter Burley Griffin. South Melbourne: Macmillan.

KAYSer, Hans. 1958. Paestum: die nomoi der drei griechischen tempel zu Paestum. Heidelberg: Lambert Schneider.

LeTHABY, W.R. 1891. Architecture, Mysticism and Myth. London: Percival \& Co.

McClain, Ernest G. 1976. The Myth of Invariance. New York: Nicolas Hays. . 1978. The Pythagorean Plato. Stony Brook: N. Hays.

Meunier, MARIO. 1980. Femmes pythagoriciennes: Fragments et Lettres. Paris: Editions de la Maisnie.

Muller, Peter. 1976. Walter Burley Griffin Memorial Lecture: the esoteric nature of Griffin's design for Canberra. ANL, MS 7817, Box 23 (vii).

NaviA, Luis E. 1990. Pythagoras: An Annotated Bibliography. New York: Garland.

Nichomachus. 1994. The Manual of Harmonics by Nicomachus the Pythagorean. Flora R. Levin, trans. Grand Rapids, MI: Phanes Press.

OLIVER, GEORGE. 1846. Historical Landmarks and Other Evidences of Freemasonry. London: R. Spencer.

- 1875. The Pythagorean Triangle; or, the science of numbers. London: J. Hogg \& Co.

RagLAN, LORD. 1964. The Temple and the House. London: Routledge and Paul.

Robertson, Howard. 1927. Architecture Explained. London: Ernest Benn.

Rudhyar, Dane. 1982. The Magic of Tone and the Art of Music. Boulder: Shambhala.

Sachs, Curt. 1937. World History of the Dance. New York: W.W. Norton \& Co.

SCHURÉ, EdOUARD. 1912. The Great Initiates. London: W. Rider \& son.

SCHNEIDER, MARIUS. 1955. Singende Steine. Kassel and Basel: Bärenreiter.

Seidenberg, Abraham. 1962. The Ritual Origin of Geometry. Archive for History of Exact Sciences 1: 488-527. 327.

Steiner, Rudolf. 1985. Macrocosm and Microcosm. D.S.O. and C.P., trans. London: Rudolf Steiner Press.

Theon of Smyrna. 1979. Mathematics useful for understanding Plato. Robert Lawlor and Deborah Lawlor, trans. San Diego: Wizard's Bookshelf.

Turnbull, JefF and Peter Y. Navaretti, eds. 1998. The Griffins in Australia and India: The complete works and projects of Walter Burley Griffin and Marion Mahony Griffin. Melbourne: Miegunyah Press.

Vatsyayan, KapILA. 1983. The Square and the Circle of the Indian Arts. New Delhi: Rolli Books International.

Wachsmuth, Günther. 1932. The Etheric Formative Forces in Cosmos, Earth and Man. Olin D. Wannamaker, trans. London: Anthroposophic Press.

WitTKOWER, RUdOLF. 1949. Architectural Principles in the Age of Humanism. London: Warburg Institute.

98 GRAHAM PONT - The Cinema as Secular Temple 


\section{About the Author}

Graham Pont, specialist in interdisciplinary studies, taught in the General Education programme at the University of New South Wales for 30 years, where he introduced the world's first undergraduate courses in Gastronomy (1978-88). Founding convener of the Symposium of Australian Gastronomy (1984) and coeditor of Landmarks of Australian Gastronomy (1988), his last appointments were a visiting professorship in the School of Science and Technology Studies, UNSW (1996-99) and a visiting fellowship to Clare Hall, Cambridge (1997-8). Trained in philosophy, his principal research area has been history and philosophy of music but his interests have also extended to environmental studies, landscape, history of gardening, philosophy of technology, bio-acoustics and wine history. He recently published the results of the first major computer analysis of Handel's music and he is completing a biography of Australia's first composer and musicologist, Isaac Nathan (1792-1864). A long study of Pythagorean ideas has proved unexpectedly relevant to his latest enthusiasm: the design philosophy of Walter Burley and Marion Mahony Griffin. 